\title{
IMPERATIVES OF THE SOCIO-ECONOMIC DEVELOPMENT OF UKRAINE IN THE CONTEXT OF THE POST-INDUSTRIAL SOCIETY FORMATION
}

\author{
Mykhaylo Voynarenko $^{1}$, Alexey Svistunov²
}

\begin{abstract}
The peculiarities of Ukraine's socio-economic development are investigated and their problematic aspects are highlighted in the article, along with their systemic analysis. The need for state regulation to increase the transformation processes in the economy under crisis conditions is justified. The objective of the study is the further development of theoretical approaches, systematisation of the analysis results and definition of the main measures to improve the efficiency of the socio-economic processes management in Ukraine to ensure implementation of the economic growth model in the short term. The subject of the study is the state of socio-economic development of Ukraine. The object of study are the transformation processes taking place in the country's economy. The study uses methods of logical generalisation, graphical, analysis, evaluation. The originality of the article lies in the approach of the authors to the definition and justification of ways to solve complex socio-economic problems of Ukraine. The new trends in management efficiency improvement of socio-economic processes in Ukraine, which are to ensure implementation of the economic growth model in the short term, are developed. The role of economic development in the investment attractiveness of the economy is justified. IT has been identified as an important activity for increasing the country's income. It has been shown that structural restructuring of an enterprise, its transformation on the basis of technological renewal in connection with realisation of the potential of informatisation and technological innovations, implies a number of structural changes in the direction of innovative development. It is confirmed that intensification of processes of informatisation, digitisation will allow to unite business, capital, industrial, scientific and trading infrastructure in the direction of achievement of world standards of development. Ways to solve the outlined problems will accelerate the socio-economic development of Ukraine, ensure sustainable development of the country's industry in the globalised economic space. At the same time, the development of cluster systems, which allow to combine science, business and government to solve the problems of sustainable development of regions, countries and their associations, is of great importance. The study also emphasises the high potential of Ukraine in the development of information systems, their active introduction in various industries of the country.
\end{abstract}

Key words: socio-economic system, crisis, government regulation, investment climate, clustering, development institutions, post-industrial society.

JEL Classification: E60, L50, O10

\section{Introduction}

Ukraine is at the stage of modern socio-economic system building. The stage is characterised by long transition period and is complicated by the deep economic crisis of recent years. In that regard, it becomes problematic to provide the further economic growth by current methods and governance mechanisms which have a number of significant shortcomings revealed in the process of

\footnotetext{
Corresponding author:

${ }^{1}$ Khmelnytskyi National University, Ukraine.

E-mail: svosn@ukr.net

ORCID: https://orcid.org/0000-0002-1301-1492

${ }^{2}$ Khmelnytskiy National University, Ukraine.

E-mail: svosn@ukr.net

ORCID: https://orcid.org/0000-0002-8474-1978
}

their practical implementation. As a result, there is a downward trend of GDP in recent years, the national currency is falling, and investor confidence is decreasing. These factors have caused a number of negative phenomena in the domestic economy. Most sectors of industry are under difficult circumstances, primarily those playing an important role in the state's economic growth, determining the investment activity and employment levels, generating the vast 
majority of budget revenues. The reasons for the decline of the domestic economy have already been identified but the situation in political, economic and financial spheres continues to worsen because of the lack of effective anti-crisis measures. That is why it is necessary to introduce scientifically grounded methods and advanced technology of the socioeconomic processes management into the domestic economy. It must be taken into account that the regulatory role of government is the main condition of the successful completion of the socio-economic system development transition process.

The issues of the socio-economic development modelling process and their management have a strong scientific basis and practical corroboration. But the difficult economic situation in the country and the obtained system analysis results require corresponding theoretical justification of the identified economic and social problems and the development of measures to remove Ukraine from the crisis.

The objective of the study is the further development of theoretical approaches, systematisation of the analysis results and definition of the main measures to improve the efficiency of the socio-economic processes management in Ukraine to ensure implementation of the economic growth model in the short term.

\section{Features of socio-economic development of Ukraine}

The problem of the certain type of management of socio-economic systems development existed at different stages of socio-economic formations at all. Economics substantiates the position that the achieved degree of social development is determined by the method of production and redistribution of national wealth. This statement is based on the longterm researchers. Herewith, the general pattern is that transition to the next stage of socio-economic relations is accompanied by qualitative changes in the productive forces and production relations interaction process.

Globally generalised socio-economic development experience of many different countries, reveals the general and the most characteristic features both to determine the specific type of socio-economic structure and to give its detailed specification and evaluation. Thus it provides an in-depth study of each country's development, taking into account its national peculiarities.

The theoretical study of socio-economic formations allows us to consider society as a whole socio-economic system operating and developing according to its economic laws based on the historical and dialectical unity of productive forces and production relations. The system also includes historical transformation processes and interaction of productive forces and production relations: unfinished production relations of the previous formation, current production relations and launched production relations for the transition to the next development stage or a new socioeconomic structure. Historically, this transition occurs spontaneously in some countries. Other countries manage to direct their economic development in accordance with economic laws, morality and culture. In the first case, one could assert the mixed model of socio-economic development. The second case is a definite country's development model.

Many scientists study Ukraine's modern social and economic state analysing economic environment and evaluating key factors of prospective economic growth along with the state's own development model formation. A protracted economic crisis testifies both the predominance of economic problems over multiple political problems and their interdependence and destructive influence on renewing production and consumption ratio. O. M. Polinkevych considers that even under such complicated circumstances the scientific and technical progress speedingup problems are still actual, as well as the 6th and 7th technological paradigms prevalence in the society (Polinkevych, 2016). Significant scientific developments of E. M. Libanova are the fundamentals of the social economy in Ukraine revealing the negative impact of economic and political situation on social justice, welfare of the population, its social protection and formation of the ideology that leads to macroeconomic instability. According to the author, there is an urgent need for social innovation and modernisation of its own society "to gain a worthy place in the world community" to solve socio-economic problems (Libanova, 2010). The necessity for the economy structural transformation for crisis overcoming is justtified in the works by S. A. Erokhin (Erokhin, 2014). V. M. Tarasevych considers investment processes to be activation means for market operational principles and domestic economy system transformation efficiency increase as, "the main competitive advantage of national capital is a prospective powerful innovation and economic potential of a national type" (Tarasevych, 2013).

Research works by V. M. Heiets and A. A. Hrytsenko are the significant contribution to the development of national economic theory and the choice of the perfect socio-economic development model. According to the results of the system studies, the researchers concluded that it is necessary to transform the modern model of socio-economic development of Ukraine into an endogenously oriented model, which will be able to ensure recovery and further development of socioeconomic processes basing on discovering its own internal mechanisms of economic growth. It will allow the country to define its own way of the post-industrial society formation (Heiets, 2015; Heiets, Hrytsenko 2013; Hrytsenko, 2014). M. I. Zveriakov reasonably 
proves that the Ukrainian political and economic model formation eventually leads to the high level of the economy monopolisation and significantly limits its growth. That is why there is the need to eliminate one of its basic structures - coalescence of business and government and "the main problem of overtaking modernisation economy creation is still there, complicated by deepening the previously unsolved socio-economic issues" (Zveriakov, 2015).

Thus, the conducted theoretical study of the theory and practice systematisation on issues relating to building a modern national socio-economic system allows to make reasoned opinion that modern Ukraine has faced the problem of choosing a new model of economic development, which would allow the national economy to enter the world economy with a high level of civilisation, progress and prosperity in a short time. However, the important stage must be accomplished for its formation that of acute political and economic crisis overcoming within the shortest possible period of time (Heiets, 2015). It should rely on scientifically grounded economic policy and state programs of socio-economic development to ensure national economy strategic development integrity along with corresponding national measures growth in political, cultural, social, and environmental spheres (Figure 1).

To fulfil the tasks of transition period stated earlier the domestic economy should count on its own potential and development of efficient socio-economic processes management. The state regulation should primarily concern state socioeconomic development programs in key spheres implying the following measures: selective support of certain branches through budgetary funding; financing of education and research; stimulation for national companies development and their use of new technology; domestic production standardisation and quality control; commodity export growth and commodity import regulation; recommendatory

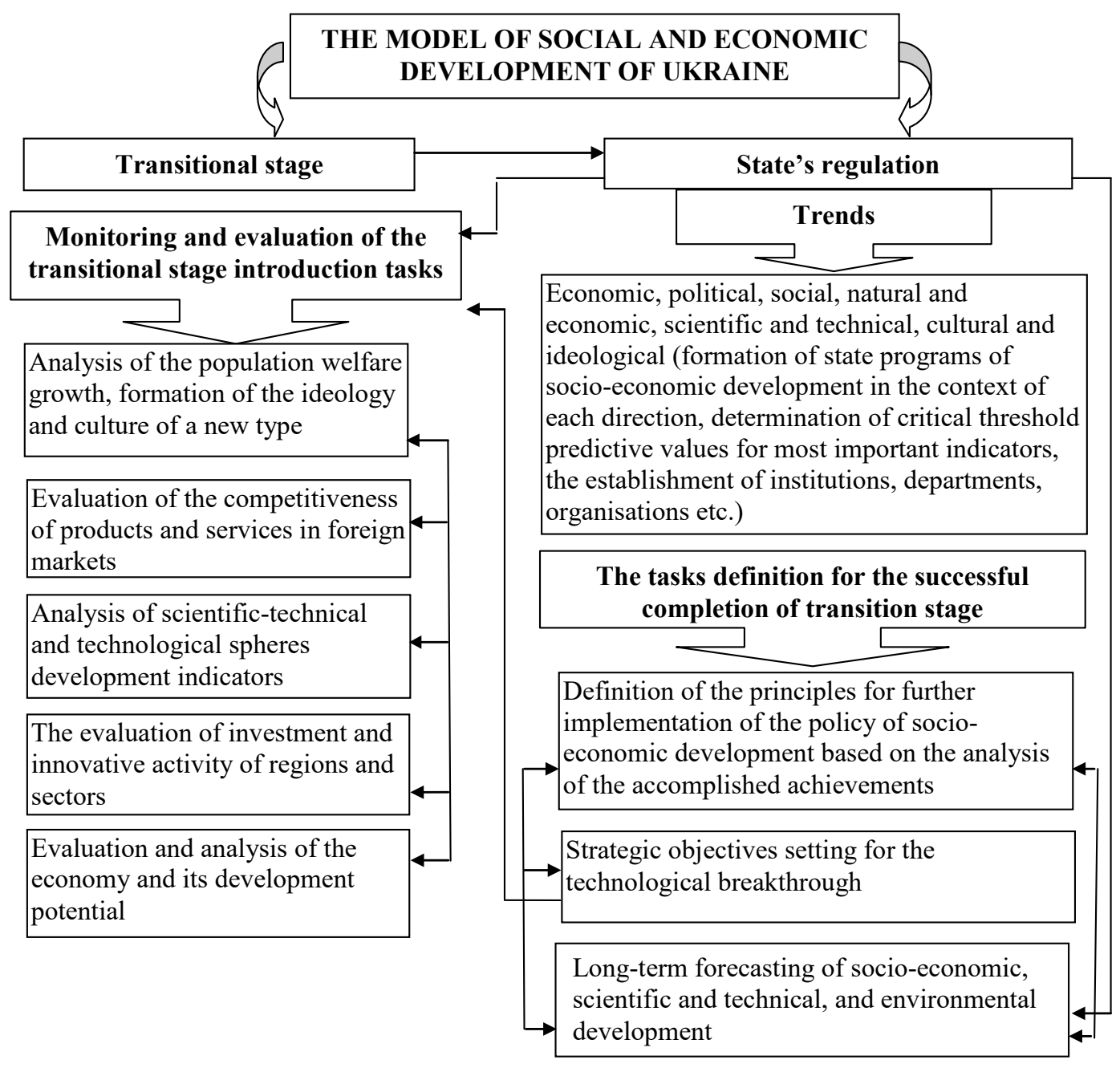

Figure 1. The sequence of the main tasks introduction of transition stage for a national model of economic development 
planning introduction ensuring socio-economic policy development in connection with economy forecasts, state progams and characteristic indicators system of key factors of state influence on social and economic processes.

Besides, with such state regulation the economy stuctural transformation process is to become systematic, that is why simultaneous structural reforms in social, political and cultural spheres are reasonable. Changes in social sphere will stipulate state policy transformation as to real income of population growth, public health service and pension system improvement, and combining social programs with employment policy. In politics, all sections of population need to follow the constitutional regulations along with quick growth of new authority intellectual potential and corresponding legislation and institutional environment. In cultural sphere there should be changes in values of social awareness, formation of a new humanitarian development paradigm, which means consumerism rejection and new values of personal and public harmony values strengthening.

\section{Problematic aspects and ways out of the crisis}

The comprehensive approach to solving the stated here problems is to guarantee Ukraine's successful economic modernisation and creating its own economic growth model. That is why structural changes are the main factor for development of the national economy strategic trends including the following: state, science and business cooperation priority raise; efficient investment sources diversification for innovation and clusterisation directed at high-tech, intellectual and informational, science intensive industries with quality production highly demand in international markets.
Thus the investment stimulation is an important prerequisite for the whole range of socio-economic problems solution at a modern stage of national economy development. The investment attraction is possible under conditions of positive real investment dynamics as a part of social resources, providing the continuity of both simple and extended reproduction process forms. The investment climate in Ukraine continues to be not attractive enough, as a result, capital moves abroad, the banking system weakens, the foreign debt of the domestic economy grows, the trade balance and the state budget unbalance, and financial and economic dependence on IMF rises. However, financial resources moved abroad exceed annual Ukraine's GDP according to today's exchange rate. This indicates that the country has lost real investments generated by more favorable country's internal sources abstract (Heiets, 2015). The quarterly survey conducted by the European Business Association indicates that companies which are operating in Ukraine worsened its assessment of the country's investment climate. Special attractiveness index of Ukraine for the third quarter totaled 2.56 points out of 5 possible points against 2.66 earlier (Figure 2).

$89 \%$ of the association member companies among 98 respondents expressed dissatisfaction with the investment climate in the country: the level of corruption combating did not correspond its scope, reforms occurred slowly, there was no effective legislative and regulatory framework. All these factors stop new investors from investing in Ukraine as a perspective market abstract.

The following types of modernisation industry investments would be the best to attract to Ukraine: investments in physical capital (equipment, facilities, development of industrial infrastructure); investments in technological capital (research, innovation, design development); investments in human capital

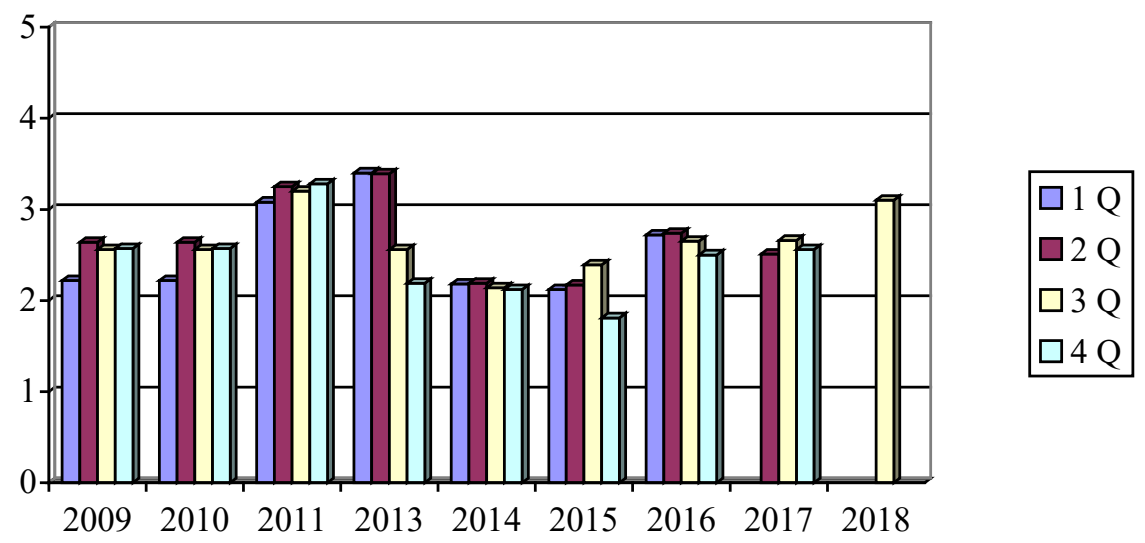

Figure 2. Scoring of the investment climate in Ukraine according to the European Business Association data

Source: (European Business Association study, 2015; Institute of Economics and Forecasting of NASU. Information resources) 
(education and government) as human and social capital in developed countries provide by far the highest rate of economic growth. According to many countries experience, foreign investments contribute to a more rational use of tangible and intangible national resources. Thus, the operation of foreign companies in the domestic market replaces lossmaking national enterprises that make it possible to redirect resources among profitable companies with modern production technologies; foreign investments increase competition in the domestic market, stimulating the introduction of advanced equipment, technologies, innovations and increasing the efficiency of their activities. A positive result of foreign investment is involvement of many manufacturers, suppliers, service companies, research and other organisations into different projects. In this case, the attraction of foreign investment becomes a catalyst of economic activity, which increases the reserves of local business further development and contributes to the attraction of prospective local investments in the economic activity. International experience also shows that the national economy efficiency stimulation occurs when foreign investments contribute to the abandoned productions revival, new industries, industrial structures and industries emergence. Economic growth in its turn leads to investment risk reduction and shortening the payback period of investments.

However, it is necessary to take into account that potential negative consequences of foreign investment may occur along with positive influential factors in national economic growth. The negative factors include the replacement of national investment and companies, as well as facilitating the movement of capital abroad on the basis of various pricing schemes and internal redistribution of financial resources.

For example, 58 billion USD in foreign currency were transferred from Ukraine in the form of dividends and interest payments to non-residents during 2008-2014. Though, payments to non-residents could belong to a significant amount of cheaper domestic investments under conditions of favorable investment policy and proper control (Heiets, 2015). Only the state can resist such negative phenomena as the domestic economy and business are still weak, therefore demanding well-grounded efficient investment policy (Heiets \& Hrytsenko, 2013).

The institutional factors occupy an important place among the many influential factors in building modern socio-economic system. Even minor violations in the institutional structure lead to significant, and in many cases irreparable complications in the economic environment hindering the state's economy growth rate. Therefore, the problem of institutional reforms is of particular importance under conditions of socioeconomic systems transformation. Accordingly, the state should create the policy of establishing the institutions, necessary for the successful formation of modern economic relations.

A key process in the initial conditions of economic reforms should be the development of information systems, as complex multisystem socio-economic structures that become the driving force for positive change in all sectors of the economy and in all areas of human activity. Information technology and systems enable to ensure economic growth through stimulating competition, promoting the expansion of production, increasing productivity provided their use is organised properly.

The following facts testify to the realisation of many directions in practical life and the advantages of our country compared with developed countries in the sphere of information computer technologies.

According to Aventures Capital fund assessment, multi-billion IT-industry has been formed in Ukraine by 2012. About 100 thousand of high-class programmers work in local IT-companies. In 2012, Ukraine was ranked first in the number of developers among the countries of Central and Eastern Europe. During the recent years, Ukraine is among the five world leaders in the software products export. Only India, China, Russia and Brazil are ahead of Ukraine. IT industry of Ukraine includes more than two hundred thousand of enterprises and their total gross income is 12 billion UAH per year. Export of informationcomputer technologies services is 9.5 billion, or $80 \%$ of the total state income (Eremin, 2015; Instytut ekonomiky ta prohnozuvannia NAN Ukrainy).

Thus, Ukraine has a powerful intellectual potential and could become one of the largest software producers in the world, primarily bringing significant income to the state. Revenue growth of the IT industry in the world over the last ten years demonstrates the great value of IT-technologies for the economic development (Figure 3).

Thus, the IT-market revenue in 2016 is expected to be almost 3.7 trillion EUR. According to the forecast data, the world GDP will be 60.7 trillion EUR. Thus, the share of the IT-market in the world GDP will be about $6.2 \%$, while in 2013 this percentage was 5\% (Eremin, 2015; Instytut ekonomiky ta prohnozuvannia NAN Ukrainy). Stimulating the domestic market of IT-technologies at the state level, primarily as a liberal fiscal policy, may be crucial for the formation of a powerful source of the GDP growth. The cluster groups forming is another essential direction in the economic policy key components formation aimed at the further socio-economic growth in the regions (Voinarenko, \& Bereza, 2013; Voinarenko, 2014).

Cluster structure can be considered a new type of production and economic model built on collaboration and co-operation of industrial and trade companies, financial and credit organisations, educational and scientific institutions (Voinarenko, \& Bereza, 2013). 


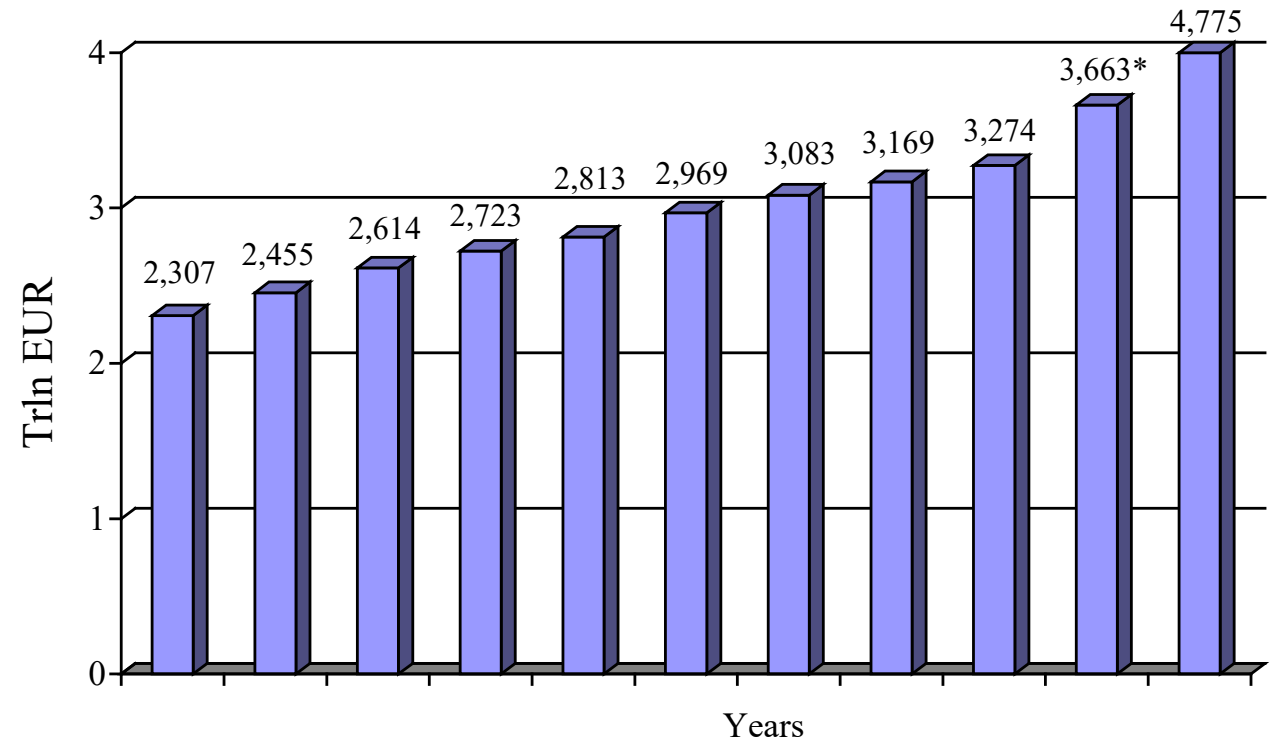

Figure 3. Dynamics revenue of the IT-technologies market in the world for the 2005-2017, trillion EUR

Source: (Eremin, 2015; Instytut ekonomiky ta prohnozuvannia NAN Ukrainy)

The experience of many developed countries confirms the national competitiveness increase as a result of industry clustering mechanisms. In this connection, there is a need for cluster system formation able to provide innovation factors transformation into the Min economic growth source. Besides, clusters mean such a combination of competition and cooperation when uniting participants in certain spheres makes successful competitiveness in other spheres possible. There is an efficient trend for Ukraine's economy development and its high position in the system of international economic relations.

Cluster policy intensifies innovation in the regions through the search for innovative products in specific areas, identification of reserves to increase their manufacturing using the latest technologies.

In addition, the policy enables to improve the regional socio-economic situation through more efficient resources use and redistribution, a decrease in prices for essential services and wealth for the people of the region, creating new jobs, etc. But clusters did not prove to be powerful economic systems in Ukraine significantly raising the competitiveness of national economy on domestic and foreign markets. This can be explained by the need of state support demanding primarily well-grounded cluster policy as a component of the state economic policy regulation able to provide an innovative approach to the new economic development direction (Voinarenko, 2014; Hrytsenko, 2014; Voinarenko, 2014).

During several decades many countries have been developing cluster strategies aimed at financial and intellectual capital integration and realisation of national economy competitive advantages. On the one hand, the cluster strategy should stimulate all-level cluster initiatives (regional, national, and international). On the other hand, they should promote existing clusters development. In our opinion, the main factors of cluster strategy realisation are: determining the most competitive companies and firms inside the cluster, which have their own development strategy; creating conditions for stable financial sources search; attracting small businesses, scientific and educational institutions to cluster structures; founding the scientific research centers.

Scientific results systematisation concerning clusters is very important for creating well-grounded cluster strategy as a part of state economic policy. It is aimed at defining state support trends for clusters in the long term. The instruments of the state policy should eliminate barriers for cluster formation, infrastructure improvement, simplification of financial sources and foreign investments attraction mechanism, remove restrictions in innovation implementation.

It should be also noted that the high level of competition on the world market, its impact on regional development and the development of the national economy, require the creation of structures in Ukraine which would ensure and coordinate the functioning of the industrial complex and its external economic relations (primarily cluster associations, their insurance and information, financial and legislative services).

\section{Conclusions}

Thus, the processes of production, exchange, distribution and consumption of goods are the basis of socio-economic system of each country. They are 
dynamic in their nature and require clear coordination and direction to achieve certain goals. It is impossible to develop universally recognised standards and ways of progress for each country despite the high level of world science and technology. However, using of the world practical experience is a necessary condition for building a new economic system.

Modern highly-developed socio-economic systems are characterised by private ownership of material resources, evolutionary development of ownership and its progressive interaction and the qualitative competitive mechanism. The transformation processes in Ukraine aimed at the building of a new economy are mostly accompanied by problematic socio-economic and crisis phenomena which have protracted nature. This suggests that there is no clearly defined model of socio-economic development in Ukraine. Besides, the mechanisms of transformation processes state regulation to build strategies and tactics, which can help to achieve the economic growth, are absent as well. Thus further theoretical research, analysis and definition of theoretical concepts of building a civilised society are required.

So, according to the results of our research of the socio-economic development of Ukraine peculiarities, we can conclude, that to create a modern socio-economic system for the country it is advisable to develop an effective public economy policy of a transition stage to the real models identified by scientists. The policy should be based on the results of scientific studies of economic development and economy growth, targeting at high technology and competitive products. Available intellectual and scientific potential create the basis for the goal achievement. The priority tasks of the country as to
European integration prove such an aim to be not only the basis for state economic strategy but also the political consolidation of society.

To ensure the further development of Ukraine in the short term we offer the following measures to be taken: the model economy with expensive labour and social standards of the population must be introduced in Ukraine; the determination of requirements for the owners of the privatised enterprises with the investment prospects of the dependent nature as to their future operations and increase in the number of jobs; facilitating the formation of cluster structures as a competitive organisational form of territorial and sectoral production model and a new element of the state economic policy aimed at ensuring socio-economic development of regions; creating structures in Ukraine which have contributed to the emergence of the new cluster and would coordinate operation of cluster organisations and their external economic relations to find points of regional growth and ensuring resist on negative influences of the high level of competition in the global market; developing the financial sector of Ukraine in the new economy growth models which would be depended from investment and should be formed in short term exclusively on market principles; returning the funds taken abroad which belong to Ukraine; developing a mechanism for increasing investment in development and research to develop IT-technology, infrastructure projects, environmental and other innovations; formation of state social support towards increasing influence for reducing inequality and overcoming the poverty, enhancing the prosperity of population; formation of efficient state policy in moral and cultural spheres which is vital for successful Ukraine's economy transformation.

\section{References:}

European Business Association study (2015). Business has worsened Ukraine's investment climate due to corruption. Available at: http://news.finance.ua/ua/news/-/361677/biznes-pogirshyv-otsinku-investklimatuukrayiny-cherez-koruptsiyu-doslidzhennya

Eremin, D. (2015). Informatcionnye tekhnologii v Ukraine: Koloss na glinianykh nogakh [Information technologies in Ukraine: Colossus with the clay feet]. Available at: https://dou.ua/lenta/articles/it-inukraine/

Erokhin, S. A. (2014). Zahalna teoriia rozvytku ta strukturna transformatsiia natsionalnoi ekonomiky [General theory of development and structural transformation of national economy]. Ekonomichny visnik, vol. 3, pp. 17-25.

Heiets, V. M. (2015). Vid kvazirynku do rynku ta investytsiinoho zrostannia [From quasi-market to market and investment growth]. Mirror of the week, vol. 30(226), p. 7.

Heiets, V. M., \& Hrytsenko, A. A. (2013). Vykhid z kryzy [Exit from the crisis]. Ukrainian economy, vol. 6(611), pp. $13-15$.

Hrytsenko, A. (2014). Ekonomicheskaia politika Ukrainy: sootnoshenie institutcionalnoi i strukturnoi sostavliaiushchikh [Economic policy of Ukraine: institutional and structural components]. Scientific works of Donetsk National Technical University. Series: Economic, vol. 1, pp. 70-79.

Hrytsenko, A. (2014). Systemna kryza yak naslidok bazovoi destruktsii ekonomiky Ukrainy i shliakhy yii podolannia [Systemic crisis as a consequence of the basic destruction of Ukraine's economy and ways to overcome it]. Bulletin of the National Bank of Ukraine, vol. 5, pp. 8-12.

Instytut ekonomiky ta prohnozuvannia NAN Ukrainy [Institute of Economics and Forecasting of NASU]. Available at: http://ief.org.ua/?lang=ru 
Ladychenko, K. I., \& Tronko, V. V. (2015). Suchasni tendentsii rozvytku svitovoho rynku informatsiinokomunikatsinykh posluh [Modern trends in world ICT market]. Efficient economy, vol. 2. Available at: http://www.statista.com/statistics/268584/worldwide-ict-revenue-since-2005/

Libanova, E. M. (2010). Sotsialna oriientatsiia rynkovoi ekonomiky yak peredumova konsolidatsii suspilstva [Social orientation of the market economy as a prerequisite for the consolidation of society]. Bulletin of the NAS of Ukraine, vol. 8, pp. 3-14.

Libanova, E. M. (2014). Nerivnist v Ukrainskomu suspilstvi: vytoky ta suchasnist [Inequality in Ukrainian society: origins and modernity]. Ukraine economy, vol. 3, pp. 4-19.

Mirror of the week (2014). There is a shortage of IT specialists in Ukraine. Available at: http://zn.ua/UKRAINE/ v-ukraine-ne-hvataet-it-specialistov-136449_html

Polinkevych, O. M. (2016). Chynnyky formuvannia vyperedzhalnoho rozvytku pidpryiemstv v umovakh hlobalnoi svitovoi kryzy [Factors in the formation of advanced development of enterprises in the global crisis]. Economic Journal - XXI, vol. 1-2 (156), pp. 59-62.

Tarasevych, V. M. (2013). Pro oriientyry i napriamy vykhodu z kryzy [About landmarks and directions of exit from crisis]. Ukraine economy, vol. 9, pp. 4-17.

Voinarenko, M., \& Bereza, A. (2013). Klasterni obiednannia: mizhnarodnyi dosvid ta ukrainski realii [Cluster associations: international experience and Ukrainian realities]. Economist, vol. 10, pp. 27-30.

Voinarenko, M. (2014). Formy I pryntsypy vzaiemodii derzhavnykh, pidpryiemnytskykh ta instytutsiinykh structur [Forms and principles of interaction of state, business and institutional structures]. The first stage of modernisation of Ukraine's economy: experience and problems. IEP NAS of Ukraine, CPU. Zaporizhzhia.

Voinarenko, M. P. (2014). Clusters in the Institutional Economics: monograph. Wloclawek: ESFII, Poland.

Zveriakov, M. I. (2013). U poshuku vykhodu iz kryzy [In search of a way out of the crisis]. Economy of Ukraine, vol. 8, pp. 4-21.

Zveriakov, M. I. (2015). Pro zminu modeli economichnoho rozvytku [About change of model of economic development]. Economy of Ukraine, vol. 635, pp. 41-49. 